\title{
Effect of Risk Management on Financial Stability of Micro Finance Institutions in Rwanda
}

\author{
Wilson Bashaija ${ }^{1}$, Jacob Niyoyita Mahina ${ }^{2, *}$ \\ ${ }^{1}$ School of Entrepreneurship, Jomo Kenyatta University of Agriculture Technology, Nairobi, Kenya \\ ${ }^{2}$ Department of Business Studies, University of Tourism, Technology and Tourism, Kigali, Rwanda
}

Email address:

wilsonbashaija17@gmail.com (W. Bashaija), niyomhj1@gmail.com (J. N. Mahina)

${ }^{*}$ Corresponding author

\section{To cite this article:}

Wilson Bashaija, Jacob Niyoyita Mahina. Effect of Risk Management on Financial Stability of Micro Finance Institutions in Rwanda. European Business \& Management. Vol. 4, No. 3, 2018, pp. 75-79. doi: 10.11648/j.ebm.20180403.12

Received: April 1, 2018; Accepted: May 31, 2018; Published: September 5, 2018

\begin{abstract}
The study sought to establish the effect of risk management on financial stability of micro finance institutions in Rwanda. In Rwandan perspective, financial system is still relatively shallow and thus potential impact on financial stability. The researcher used Theory of Corporate Risk Management. Research Design, Population, Sampling Frame and Size, Data Collection Instruments, Data Collection Procedure, Pilot Test, Reliability of the Instrument, Validity, and Data Processing and analysis were used during the study. Data analysis was descriptive statistics and inferential statistics using Statistical Packages for Social Sciences (SPSS) version 21. SPSS produced frequencies, descriptive and inferential statistics which was used to derive conclusions and generalizations regarding the population. The analysis of variance (ANOVA) was checked to reveal the overall model of significance. A critical $p$ value of 0.05 was used to determine whether the overall model is significant or not. The results were indicated that as per the variable. Risk management has a positive and significant effect on compliance and financial stability on Financial Stability of MFI. The study recommended that there must be a policy for the MFI to try to stick to one bank in order to create a good relationship with the bank. The study also recommends that the government of Rwandans should timely review the timelines set for completing their full risk-based assessment of the effectiveness of their financial reporting controls and for addressing identified gaps and weaknesses, to ensure that they are timely reported.
\end{abstract}

Keywords: Risk Management, Financial Stability, Micro Finance Institutions

\section{Introduction}

Regulation now being enacted for Microfinance seeks not only to protect the financial system and depositors, but also to promote poor people's access to formal finance. Tambunlertchai urged that the primary reasons for prudential regulation of depository institutions are to protect the country's financial system by preventing the failure of one institution from leading to the failure of others, and to protect small depositors who are not well-positioned to monitor the institution's financial soundness themselves [23]. Patro, Qi \& Sun Argue that, one important factor that reduced the exposure of Japanese financial institutions to the risks realized in the global financial crisis was Japan's (micro) prudential regulation regime that had been significantly improved following Japan's own financial crisis in the 1990s
[17]. The Central Bank of Malaysia has been proactive in the development of strong domestic and regional framework to enhance the Malaysian financial sector and this has been accompanied by appropriate prudential safeguards to ensure that the nation's best interest and financial stability are preserved. In European Central Bank, The Financial Stability Review provides an overview of the possible sources of risk and vulnerability to financial stability in the euro area. Its aim is to promote awareness of issues that are relevant for safeguarding the stability of the euro area financial system, both within the financial industry and among the public. The risk-based approach to financial regulation that seem to be adopted by the Bank of Ghana shows that while there may be no major variances in the structure of MFS assets, they are differentiated by the structure of their liabilities (how assets and operations are funded) and the adequacy of qualifying capital in leveraging additional resources to fund operations 
[3]. The Assessment Team found the formal financial sector regulatory framework does not pose. While measures in favor of consumer protection are fairly consensual and have already led to a number of very constructive initiatives in the microfinance sector measures to control interest rates that remain controversial.

\subsection{Statement of the Problem}

Microfinance Institutions helps to expand coverage, make financial services more affordable and secure, competitive and efficient by reducing transaction costs and protect customers' deposits and investment. Micro finance in developed countries is scarce, likely because the sector is still young and poorly delimited. The division between microcredit and small business financing remains unclear. Depending on the provider, similar loans are classified as micro-loans, conventional loans, consumer loans, or SME loans. Kahuthu Stated that increase in unsafe lending and risky investments led to financial turmoil in the world and was particularly severe in the US and European Union countries in 2007 and 2008 [13], the views shared by Knell \& Stix was to avoid similar experiences in Kenya, where the credit management had to be addressed [14]. There has been no study undertaken in Rwanda to establish the effect of Compliance and Financial Stability on Financial Stability of Micro Finance Institutions ( MFI) that have been licensed to carry out deposit taking business and this is the knowledge gap motivating this study. It is against this background that a study should be carried out on the relationship between Compliance and Financial Stability of MFIs in Rwanda.

\subsection{Specific Objectives}

To assess the Effect of Risk Management on Financial Stability of Micro Finance Institutions in Rwanda.

\subsection{Research Hypothesis}

$\mathrm{HO}_{3}$ : There is no significant relationship between Risk Management and Financial Stability of Micro Finance Institutions in Rwanda.

\section{Theory}

\section{Corporate Risk Management Theory}

Tornatzky, Fleischer \& Chakrabarti theoretical research efforts and the design of applied methods for corporate risk management are stalled by the inability to decide which theoretical approach to follow. The theory formulated by Rogers states that there are two dominant views on adoption one which holds that Adoption can be seen as having or not having an innovation and another view that it can be seen as using the innovation versus not having it [19]. The theory by Rogers considered risk management models developed within the body of the following theories of the firm: financial theory, agency theory, stakeholder theory and new institutional economics, Adoption is according to Rogers, a decision to make full use of an innovation as the best course of action available and rejection is a decision not to adopt an innovation [19]." According to this view the line between adoption and use of the innovation is thin or non-existent. Rogers argues, that the adoption process is the process through which a decision-making unit passes from first knowledge of an innovation, to forming an attitude toward the innovation, to a decision to adopt or reject, to implementation of the new idea, and finally to confirmation of this decision. In this course of events the adoption process is considered to be merely a mental exercise until implementation takes place. In this dissertation the core understanding of the term adoption is "having versus not having" [24] rather than "not having versus using" [19].

Theory formulated by Tufano constructed two classes of explanations for managers' choices of risk management activities on behalf of their firms [25]; one class of explanations focuses on risk management as a means to maximize shareholder value, and the second focuses on risk management as a means to maximize managers' private utility. Theory by Levine notes that the market perfections as a rationale for risk management makes risk management irrelevant because shareholders can replicate at their level any strategy adopted by the firm [15]. Theory by Smith \& Stulz claims that risk management can reduce either the overinvestment or underinvestment costs resulting from the non-observability of managerial actions [20]. The effectiveness of such policy is, in general, inversely related to the volatility of the cash flows generated by the firm. Theory formulated by Smith \& Stulz implies that firms will manage risk to decrease cash flow volatility because it reduces one of the costs related to managerial discretion in presence of information asymmetry for shareholders [20]. Theory by Smith \& Stulz notes that market imperfections such as taxes, financial distress costs, and investment opportunities are advanced in the literature to explain why firms manage risks. Assumptions analysis identifies risks to the project from inaccuracy, instability, inconsistency or incompleteness of assumptions [20]. It is preferable to have the assumptions accurate, complete and consistent; but, in practice, it is not always possible. So, it is important for the project management team to review the justification or strength or support of the assumptions made. The risks are directly proportional to the consequences or the impacts to the project objectives if the assumption turns out to be wrong. Nonetheless, critics say that a significant, original contribution to Eco criticism in showing how we might learn from the association and overlap of varied types and sites of risk, including climate change, plastics, and nuclear weapons. Risk Criticism does important work in modeling methods for engaging profitably with both the problematic concept of risk "management" and the imaginative discourses that arise from and inform understanding of global threat highly recommended.

According to the international Organization of Standardization (ISO) the risk management process has been presented as a list of coordinated activities consisting of; recognition of risks, ranking of risks, responding to risks, 
tolerate, treat, transfer, terminate, resourcing controls, reaction planning, reporting and monitoring risk performance reviewing the risk management framework. The risk Management Process has been modeled.

\section{Research Methodology}

\subsection{Research Design}

This study adopted descriptive cross sectional design. Zikmund et al say that descriptive research is to describe characteristics of objects, people, groups, organizations, or environments [27]. In other words, descriptive research tries to "paint a picture" of a given situation by addressing who, what, when, where, and how questions [27]. Descriptive research design is appropriate for this study as it helped in understanding the relationship between Compliance and Financial Stability of Micro Finance Institutions in Rwanda and therefore answers the "what" question of the study. The researcher was use of longitudinal survey design since the nature of research also relied on secondary data of published financial reports of Micro Finance Institutions in Rwanda.

\subsection{Target Population}

According to Mugenda \& Mugenda a population refers to an entire group of individuals, events or objects having a common observable characteristic [16]. In other words, population is the aggregate of all that conforms to a given specification. Researcher targeted nine MFI senior management (Chief executive officer, finance manager, credit manager, risk manager and senior accountant), seven MFI directors and twelve shareholders of the MFI.

\subsection{Sample Size}

The researcher adopted stratified random sampling technique where all units from the sampling frame have an equal chance to be drawn and to occur in the sample. The researcher used a sample representation of thirty $(30 \%)$ of 152 from each of the strata identified and to ensure equal representation.

\section{Data Processing and Analysis}

The data was collected and analyzed, with respect to the study objectives, using both descriptive and inferential statistics. The tools of analysis adopted in this study were Statistical Package for Social Sciences (SPSS) version 21 for descriptive data and advanced Microsoft excel for quantitative data. The data was analyzed using descriptive statistics such as mode, median, mean, standard deviation.

Summarized background, a little on the objective, statement of the problem and mention some literature (citations) were highlighted.

\section{Risk Management}

Risk management involves identifying the types of risk exposure within the company, measuring those potential risks, proposing means to hedge, insure or mitigate some of the risks and estimating the impact of various risks on the future earnings of the company [6].

(a). Assessment of Fraud Risk

The study sought to predict, detect, and respond to the risks and vulnerabilities that come from global corruption, litigation, fraud, financial mismanagement, and other threats.

Table 1. Assessment of Fraud Risk.

\begin{tabular}{llllllll}
\hline Risk management & Strongly disagree (\%) & Disagree (\%) & Not sure (\%) & Agree (\%) & Strongly agree (\%) & Mean & Std. Deviation \\
\hline RM 1 & 0 & 20 & 16 & 41 & 23 & 3.68 & 1.041 \\
RM 2 & 0 & 0 & 19 & 44 & 37 & 4.17 & .740 \\
RM 3 & 0 & 5 & 18 & 54 & 24 & 3.97 & .775 \\
RM 4 & 0 & 3 & 15 & 50 & 32 & 4.11 & .762 \\
\hline
\end{tabular}

The respondents, depict the the assessment of fraud risk consider opportunities for unauthorized acquisition, use, or disposal of assets, altering the organization's reporting records or committing other inappropriate acts. The study indicated that majority (64\%) of respondents agreed and strongly agreed, while $16 \%$ were not sure and $20 \%$ disagreed with the statement. This is an indication that there are sound controls on fraud risk and management of assets. The results focused on fraud risk assessment team, engages in brainstorming sessions to identify incentives, pressures and opportunities to commit fraud; the risk of management override of controls; and the fraud risks that are most relevant to our organization.

The respondents in Table above indicated that majority (81\%) agreed and strongly agreed, while $19 \%$ were not sure whether your bank has a strategy for liquidity risk management approved by banks' management. This implies that bank has a strategy for liquidity risk management. This is in agreement with [26] whose study on a strategy for liquidity risk management; results revealed that the management of risk, asset and liability remain the core function of banking. Further [8], revealed that Liquidity risk has been one of the main drivers of the current credit crisis.

The study findings shows that majority (78\%) agreed and strongly agreed, while $18 \%$ were not sure and $4 \%$ disagreed that ratios of maturity transformation of short term sources in long term placements. The study findings also relate to the importance of supervisors assessing the adequacy of a bank's liquidity risk management framework and its level of liquidity, and suggest steps that supervisors should take if these are deemed inadequate. This is in line with the study by [18].

The results shows that, majority $(82 \%)$ agreed and strongly agreed, while $15 \%$ were not sure and $3 \%$ disagreed whether the Ratios of maturity transformation of short term sources in long term placements. Based on participant's responses, it 
implies that there is maturity transformation of short term sources. This concurs with the study of [1]. On whose findings indicated that a bank's liquidity situation, particularly in a crisis, will be more affected more than the reserve of cash and highly liquid securities.

(b). Liquidity risk

The study sought to examine liquidity risks in Microfinance Institutions as shown in Table 2 below

Table 2. Liquidity risk.

\begin{tabular}{|c|c|c|c|c|c|c|c|}
\hline Risk management & Strongly disagree (\%) & Disagree (\%) & Not sure (\%) & Agree (\%) & Strongly agree $(\%)$ & Mean & Std. Deviation \\
\hline RM 5 & 0 & 0 & 20 & 54 & 26 & 4.05 & .687 \\
\hline RM 6 & 0 & 3 & 16 & 49 & 32 & 4.12 & .755 \\
\hline RM 7 & 0 & 1 & 16 & 62 & 21 & 4.04 & .623 \\
\hline RM 8 & 0 & 11 & 27 & 41 & 20 & 3.69 & .935 \\
\hline
\end{tabular}

The study indicated that majority $(80 \%)$ agreed and strongly agreed, while $20 \%$ were not sure on Risk Management. However, this shows that there is strong interaction on liquidity risk and other risks. This corroborates with the study of Duffie \& Singleton that a bank should recognize and consider the strong interactions between liquidity risk and the other types of risk to which it is exposed. These include interest rate, credit, operational, legal and reputational risks, which may influence a bank's liquidity profile [7]. The research findings revealed that majority (81\%) of respondents agreed and strongly agreed that the assessment of fraud risk consider the opportunities for wilful violations of laws or governmental regulations that could have a material direct or indirect impact on external financial reporting while $16 \%$ were not sure and 3\% disagreed with the statement. From the above responses, this donates that there are controls on assessment of fraud. This study concur with that of deterring fraud establishing an atmosphere and perception that the likelihood of getting caught is so high that it scares potential fraud perpetrators away is by far the best situation in terms of managing fraud risk [7].

From Table above the study indicated that majority $(83 \%)$ of respondents revealed that the organization perform a risk assessment to consider risk related to fraudulent financial reporting, management override, potential loss of assets and corruption, while those who were not sure were $16 \%$, disagreed was $1 \%$. This implies that there are sound controls on risk assessment. The results agree with the findings by Duffie \& Singleton whose study reveals that Deterring fraud establishing an atmosphere and perception that the likelihood of getting caught is so high that it scares potential fraud perpetrators away is by far the best situation in terms of managing fraud risk [7].

Majority (61\%) of respondents agreed and strongly agreed on the organization's risk assessment process, while $27 \%$ were not sure and $12 \%$ disagreed. From respondents' views it implies that there are organization's risk assessment processes in place. Findings reveal that effectively overseeing management and addressing the risk of management override, audit committees increase the likelihood of preventing, deterring, and detecting fraudulent financial reporting.

(c). The Operational Risk Management

Results in Table 3 indicate Risk Management Rules exhaustively cover the necessary arrangements.

Table 3. The Operational Risk Management.

\begin{tabular}{|c|c|c|c|c|c|c|c|}
\hline Risk Management & Strongly disagree (\%) & Disagree (\%) & Not sure $(\%)$ & Agree (\%) & Strongly agree $(\%)$ & Mean & Std. Deviation \\
\hline RM (9) & 0 & 20 & 16 & 41 & 23 & 3.68 & 1.041 \\
\hline RM (10) & 0 & 0 & 19 & 44 & 37 & 4.17 & .740 \\
\hline $\mathrm{RM}(11)$ & 0 & 5 & 18 & 54 & 24 & 3.97 & .775 \\
\hline
\end{tabular}

Most of respondents (64\%) agree and strongly agree that the Operational Risk Management Rules exhaustively cover the arrangements, while $16 \%$ are not sure while $20 \%$ disagree with the statement. This indicates that the organization has strong system to manage risks. This concur with Gulshan urged that Operational Risk Management Rules exhaustively cover the arrangements necessary for comprehensive operational risk management and specifies the arrangements appropriately in a manner befitting the scale and nature of the financial institution's business [11]. From Table above, most of respondents $(81 \%)$ agree that the company's assets under management (investment funds) evaluated by an administrator outside your group, while 19\% are neutral. Based on the respondents above, it implies that there is proper management of assets. This is in agreement with [12]. Majority of respondents agree (78\%) that the Board of Directors or equivalent organization provide a system to fully disseminate the relevant internal rules and operational procedures while $15 \%$ are neutral and 5\% disagree with the statement this is in line with [2]. who revealed that the Company has selected the Company with Audit and Supervisory Committee system described in the Companies Act of Japan for its organizational structure.

\section{Recommendations}

\section{Risk Management on Financial Stability}

The study recommended that there must be a policy for the MFI to try to stick to one bank in order to create a good relationship with the bank. Standard setting bodies should review their principles for governance, taking into consideration the sound risk governance practices set out in the report. At the same time, Government recommends to strengthen risk management practices as one of the main 
lessons from the financial crisis, for both financial and nonfinancial companies. The study recommended that government authorities need to better assess the effectiveness of a firm's risk governance framework, and more specifically its risk culture, to help ensure the sound management of risk through the economic cycle. Supervisors need to strengthen their assessment of risk governance frameworks to encompass an integrated view across all aspects of the framework.

\section{Conclusion}

The results of ANOVA test which reveal that Risk Management has significant effect on Financial Stability in the Micro Financial Institutions of Rwanda. The study thus rejects the null hypothesis and concludes that there is significant relationship between Risk Management and Financial Stability in the Micro Financial Institutions of Rwanda. Results indicated that all items manifest a mean greater than 3.4 assures that the Risk Management is well done. On analysis four factors emerged highlighting the importance after establishment of goodness of measure of the data using factor analysis, the hypothesis on the effect of resources on success of tour businesses owned by indigenous.

\section{References}

[1] Admati, A., \& Hellwig, M. (2014). The bankers' new clothes: What's wrong with banking and what to do about it? Princeton University Press.

[2] Agumba, J. (2012). Competitive strategies in response to challenges of external environment by Water Resources Management Authority in Kenya. Unpublished MBA Thesis, University of Nairobi.

[3] Agyekum, K. F. (2017). A trajectory of financial inclusion towards economic inclusion: Empirical.

[4] Brody, R. G., Melendy, S. R., \& Perri, F. S. (2012). Commentary from the American Accounting Association's 2011 annual meeting panel on emerging issues in fraud research. Accounting Horizons, 26(3), 513-531.

[5] Cole, R. V., \& Tambunlertchai, S. (2017). The Future of AsiaPacific Economies: Pacific Islands at the crossroads. Canberra, ACT: National Centre for Development Studies, Research School of Pacific Studies, the Australian National University.

[6] Dionne, G. (2013). Risk management: History, definition, and critique. Risk Management and Insurance Review, 16(2), 147166.

[7] Duffie, D., \& Singleton, K. J. (2012). Credit risk: pricing, measurement, and management. Princeton University Press.

[8] Galati, G., \& Moessner, R. (2013). Macroprudential policy-a literature review. Journal of Economic Surveys, 27(5), 846878 .

[9] Giles, S. (2012). Managing fraud risk: a practical guide for directors and managers. John Wiley \& Sons.

[10] Guiso, L. (2010). A Trist-Driven Financial Crisis. Implications for the Future of Financial Markets.

[11] Gulshan, S. S. (2011). Management Principles and Practices by Lallan Prasad and SS Gulshan. Excel Books India.

[12] Hamdan, M., \& Low, P. K. (2014). Sovereign Wealth Funds and Wealth Management in Brunei Darussalam. Business Journal for Entrepreneurs, 2014(1).

[13] Kahuthu, K. M. (2016). The effect of trade finance on the performance of commercial banks in Kenya (doctoral dissertation, school of business, university of Nairobi).

[14] Knell, M., \& Stix, H. (2010). Trust in Banks-Evidence from normal times and from times of crises.

[15] Levine, R. (2005). Finance and growth: theory and evidence. Handbook of economic growth, 1, 865-934.

[16] Mugenda, O. M., \& Mugenda A. G. (2008). Research Methods; Quantitative and Qualitative Approaches. Nairobi: Act s Press. Musau, S. M. (2017). The Role of Strategic Management Practices on Competitiveness of Floriculture Industry in Kenya: A Case of Kiambu County (Doctoral dissertation, United States International University-Africa).

[17] Patro, D. K., Qi, M., \& Sun, X. (2013). A simple indicator of systemic risk. Journal of Financial Stability, 9(1), 105-116.

[18] Rehman, A. A., Benamraoui, A., \& Dad, A. M. (2017). A comparative study of Islamic and conventional banks' risk management practices: empirical evidence from Pakistan. Journal of Banking Regulation, 1-14.

[19] Rogers, E. M. (1995). Diffusion of Innovations: modifications of a model for telecommunications. In Die Diffusion von Innovationen in der Telekommunikation (pp. 25-38). Springer Berlin Heidelberg.

[20] Smith, C. W., \& Stulz, R. M. (1985). The determinants of firms' hedging policies. Journal of financial and quantitative analysis, 20(4), 391-405.

[21] Smithson, B. J., Aknin, J. D., Lichac, G. J., Moncrief, R. L., \& Winblad, W. O. (1993). U.S. Patent No. 5,240,417. Washington, DC: U.S. Patent and Trademark Office.

[22] Stulz, R., \& Johnson, H. (1985). An analysis of secured debt. Journal of financial Economics, 14(4), 501-521.

[23] Tambunlertchai, K. (2017). Financial Inclusion in Myanmar: What Factors Determine Access to Saving and Credit Products For Informal Sector Workers? Southeast Asian Journal of Economics, 5(1), 77-107.

[24] Tornatzky, L. G., Fleischer, M., \& Chakrabarti, A. K. (1990). Processes of technological 'innovation. Lexington Books.

[25] Tufano, P. (1996). Who manages risk? An empirical examination of risk management practices in the gold mining industry. The Journal of Finance, 51(4), 1097-1137.0.

[26] Waemustafa, W., \& Sukri, S. (2016). Systematic and unsystematic risk determinants of liquidity risk between Islamic and conventional banks.

[27] Zikmund, W. G., Babin, B. J., Carr, J. C., \& Griffin, M. (2013). Business research methods. Cengage Learning. 